\title{
Characteristics and Pregnancy Outcomes of Pregnant Women Asymptomatic for Bacterial Vaginosis
}

\author{
Deborah B. Nelson - Scarlett Bellamy · Bonnie A. Clothier - George A. Macones • \\ Irving Nachamkin · Althea Ruffin · Lynne Allen-Taylor · Frank K. Friedenberg
}

Published online: 22 November 2007

(C) Springer Science+Business Media, LLC 2007

\section{Erratum to: Matern Child Health J \\ DOI 10.1007/s10995-007-0239-7}

The following authors were accidentally omitted from this article: Bonnie A. Clothier and George A. Macones.

The online version of the original article can be found under doi: 10.1007/s10995-007-0239-7.

D. B. Nelson $(\bowtie)$

Department of Public Health College of Health Professions, Temple University, 1700 North Broad Street - Room 304F, Philadelphia, PA 19122, USA

e-mail: dnelson@temple.edu

D. B. Nelson

Department of Ob/Gyn School of Medicine, Temple University, Philadelphia, USA

S. Bellamy · B. A. Clothier · A. Ruffin · L. Allen-Taylor Center for Clinical Epidemiology and Biostatistics, Department of Biostatistics and Epidemiology, University of Pennsylvania School of Medicine, Philadelphia, USA

\section{G. A. Macones}

Department of Obstetrics and Gynecology, Washington

University in St. Louis School of Medicine, St. Louis, USA

I. Nachamkin

Clinical Microbiology Laboratory, Department of Pathology and Laboratory Medicine, University of Pennsylvania, Philadelphia, USA

F. K. Friedenberg Department of Medicine, Division of Gastroenterology, Temple University, Philadelphia, USA 